\title{
Distribution and Endemism of Angiosperms in the Atlantic Forest
}

\author{
Márcio de Souza Werneck ${ }^{* *}$, Marcos Eduardo Guerra Sobral², Cinthia Tamara Vieira Rocha ${ }^{3}$, \\ Elena Charlotte Landau ${ }^{4} \&$ João Renato Stehmann ${ }^{5}$
}

\author{
${ }^{1}$ Centro de Ciências Naturais e Humanas, Universidade Federal do ABC - UFABC, Santo André, SP, Brazil \\ ${ }^{2}$ Departamento de Ciências Naturais, Universidade Federal de São João Del-Rei - UFSJ, São João Del Rei, MG, Brazil \\ ${ }^{3}$ Centro Universitário de Belo Horizonte - UNI-BH, Belo Horizonte, MG, Brazil \\ ${ }^{4}$ Empresa Brasileira de Pesquisa Agropecuária - Embrapa Milho e Sorgo, Sete Lagoas, MG, Brazil \\ ${ }^{5}$ Departamento de Botânica, Universidade Federal de Minas Gerais - UFMG, Belo Horizonte, MG, Brazil
}

\begin{abstract}
This work represents the first large scale initiative to map endemic plant species in the Atlantic Forest. The region is home to 13,708 angiosperm species of which 6,663 are estimated to be endemic. Angiosperm spatial patterns, their representation in the existing protected areas system, sampling biases and gaps on the knowledge about species distributions are analyzed. As a result of this work, an extensive species database was created, which will be available to conservation decision makers and research institutions in Brazil.
\end{abstract}

Key words: Biodiversity Databases, Endemism, GIS, Protected Areas, Sampling Bias.

\section{Introduction}

A taxon is endemic if confined to a particular area due to historical, ecological or physiological reasons. However, the definition of endemism has proven difficult, and use of different definitions prevents direct comparison among regions (Peterson \& Watson 1998). Additionally, the concept of endemism very much depends on the knowledge of the geographical range of a species (Harrison et al. 2006). Generally, a newly discovered species has only been found in a unique site, and with the knowledge of that moment, it should be considered endemic. However, if it is found on other site or biome, this definition is revised. Thus, endemism refers to distributions restricted to a given geographic region either by physical, climatic or biological factors, whereas the region can be based on human political boundaries or natural geographic features (Peterson \& Watson 1998).

The Atlantic Forest is one of the most endangered ecosystems on earth, being considered one of the 34 hotspots for biodiversity conservation in a global context (Mittermeier et al. 2004). High diversity of angiosperms, with many endemic species, is feature of its flora. Angiosperms

\footnotetext{
*Send correspondence to: Márcio de Souza Werneck

Centro de Ciências Naturais e Humanas,

Universidade Federal do ABC - UFABC,

Rua Santa Adélia, 166, CEP 09210-170,

Santo André, SP, Brasil

e-mail: marcio.werneck@ufabc.edu.br
}

represent approximately $94 \%$ of all vascular plants in Atlantic Forest, and are distributed in 208 plant families. Its species richness was recently evaluated, totalizing 13,708 angiosperm species, of which 6,663 are endemic (Stehmann et al. 2009). On the other hand, there is little knowledge about the general distribution patterns of endemism.

Floristic data that cover the distribution of whole angiosperm families all over the Atlantic Forest are still scarce, since not all families are published in the Flora Neotropica monograph series and the data from other sources are very fragmented. Taxonomic reviews are disperse and incomplete for the Brazilian Flora. However, it should be emphasized that due to many of these studies, there was a major advance in the knowledge of species distribution data in Brazil. Two recent studies are noteworthy in this regard. Stehmann et al. (2009) presented a list of species occurring in the Atlantic Forest, providing data on the vegetation type, where each species occurs, an indication of endemism and threat category in the different red lists published. Other advance was the publication of Forzza et al. (2010), which despite being only a cheklist, offers information on the occurrence of each species in Brazil as well as biomes, including the Atlantic Forest. Recently, more information was added such as vegetation type, life forms and substrate (Forzza et al. 2011). Both publications consider that species exclusively occurring within the biome, such as the Atlantic Forest, are endemics. 
The lack of information about the distribution of angiosperms in the Atlantic Forest makes it difficult to answer some essential questions for the conservation of biological diversity. Here we used GIS to analyze a large georeferenced database of locations where endemic angiosperms from Atlantic Forest were observed, addressing the following questions: (1) How are endemic angiosperms distributed in the Atlantic Forest?; (2) Which areas present higher concentration of endemic species?; (3) How much endemic species have populations within special areas - like protected areas or biodiversity corridors?; (4) Based on the distributions of angiosperm endemics in the Atlantic Forest, are there any gaps of records, either by lack of research or by the absence of remaining natural vegetation?

\section{Material and Methods}

The study area is the original extent of the Atlantic Forest Domain, including all vegetation types, defined according to the Brazilian legislation (Atlantic Forest law $\mathrm{N}^{\circ} 11,428$, of December 22, 2006). The endemic angiosperm species of the Atlantic Forest were selected from a list presented by Stehmann et al. (2009). In this paper, we treat species restricted to the geographical area covered by Atlantic Forest as endemic species, according to Peterson \& Watson (1998). Species occurrence data were obtained from several sources, such as Flora Neotropica monograph series; papers on systematics; and records of the herbaria collections from SpeciesLink (http://www.splink.org.br/), a distributed information system that integrates primary data from biological collections from Brazil. The data were consolidated through the establishment of a georeferenced database. When specific geographic coordinates were not provided for a locality, geographic coordinates for the locality record of each species were taken from several sources. We identify their coordinates using databases like the list of municipalities (counties) and villages in Brazil (Instituto Brasileiro de Geografia e Estatística; http://www. ibge.gov.br) and Internet location gazetteers (GeoLoc tool, available on the SpeciesLink website; http://splink.cria. org.br/geoloc?criaLANG=pt). Google Earth (http://earth. google.com/intl/pt/) was also used to virtually recreate the collection trip using the site descriptions, which identified towns, road names and numbers, and distance (in $\mathrm{km}$ ) travelled from town A to town B, using the path ruler.

We performed a pre-selection of SpeciesLink records used in the analyses, including only specimens whose identity was determined by specialist taxonomists and excluding those cultivated and with questionable location. Each available record was screened for nomenclatural errors and updates. In cases where there were more than one record of the occurrence of a species in the same location, we considered only one of the records. After applying these procedures, we used a database with 28,053 records of occurrence of 3,345 species (50.2\% of total of endemic angiosperms), distributed among 434 genera (40.7\% of total) and 81 botanical families ( $50.9 \%$ of total), to analyze the distribution of endemic angiosperms. Figure la shows the distribution of records in the Atlantic Forest.

In order to perform the geographic analyses, $1^{\circ} \times 1^{\circ}$ grid cells were used as units of study. This was done to ease data manipulation and partly to reduce the effects of sampling artifacts such as mapping errors and unsampled grid cells in sparsely inhabited areas (roadmap effect). For each grid cell, endemic species richness was calculated as the total number of endemic angiosperms present. The endemic species richness of each latitudinal band was also calculated. The species distribution data in grid cells were plotted in maps using the programs ArcGIS 9 (Esri 2004).

A non-parametric estimator of species richness (first-order Jackknife) was used to identify the well-surveyed grid cells (Colwell \& Coddington 1994). The decision framework provided by Brose et al. (2003) helped deciding which Jackknife estimator suits better the available data. The Jackknife 1 estimator has been shown to give better results than the other incidence-based estimators, since both seem to be less affected by grain size (Hortal et al. 2006). In every grid cell, the number of database records was used as a surrogate of sampling effort (Hortal \& Lobo 2005). We use a biodiversity-oriented Geographical information system (DIVA-GIS 7.4, http://www.diva-gis.org/) for the calculation of Jackknifel estimator of species numbers per grid cell. The ratio of observed to predicted species richness (first-order Jackknife estimator) was used as a measure of completeness of each grid cell following Soberón et al. (2007). We assume that grid cells with completeness values higher than $70 \%$ using the formerly mentioned estimator are well-surveyed (following Sánchez-Fernández et al. 2008).

The presence of each endemic species was recorded into the Atlantic Forest Biodiversity Corridors (Sanderson et al. 2003), Priority Areas for Conservation in the Brazilian Atlantic Forest (Conservation International do Brasil et al. 2000), and Brazilian Protected Areas. The Atlantic Forest Biodiversity Corridors represent large regional planning units comprising a mosaic of land uses and key conservation areas and is divided into: Northeastern Biodiversity Corridor, Atlantic Forest Central Corridor, and Serra do Mar Corridor. The Priority Areas for Conservation consolidates information on the biological diversity of the Atlantic Forest and are classified into 'extreme biological importance', 'very-high biological importance', and 'high biological importance. The Brazilian protected areas are divided into two types (Silva 2005): strictly protected (IUCN categories I, II and III), with biodiversity conservation as the principal objective, and sustainable use areas (IUCN categories IV, V and VI), allowing for varying forms of use or extraction, with biodiversity protection as a secondary objective.

\section{Results}

There are few areas with many species, and many areas with few species (Figure 2). Endemic angiosperm richness is particularly high in the west and central Rio de Janeiro 


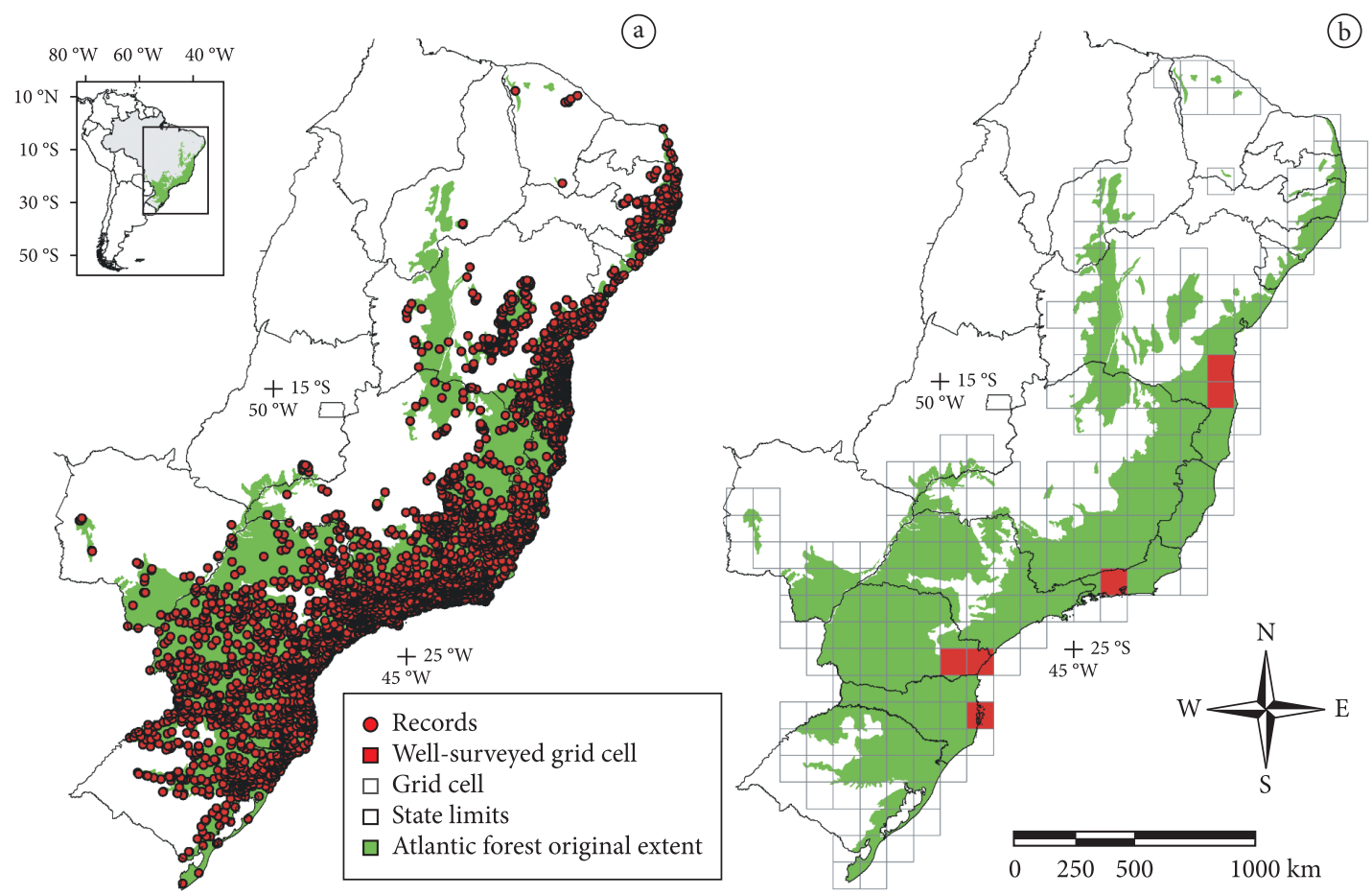

Figure 1. a) Distribution of 28,053 records of occurrence of 3,345 endemic species from Atlantic Forest. b) The grid system with 231 cells of $1^{\circ} \times 1^{\circ}$ latitude/longitude overlaying the Atlantic Forest Domain original extent and distribution of the five grid cells classified as well-surveyed according to completeness results using the Jackknifel estimator.

state, central Espírito Santo state, east of São Paulo and Paraná states, and southern Bahia state. The highest number of endemic angiosperms in a single grid cell is 978 and occurs in the region of Rio de Janeiro city. Going from north to south, the other principal areas with high endemic angiosperms richness are (1) the Itabuna region, southern Bahia state (531 species); (2) Rio Doce region, central Espírito Santo state (690 species); (3) Serra dos Órgãos, central Rio de Janeiro state (746 species); (4) Serra do Mar, eastern São Paulo State (562 species); and (5) Serra Geral and Serra do Mar, eastern Paraná state (two grid cells with more than 430 species each).

The observed species richness and number of database records per grid cell were highly correlated (Spearman rank correlation, $r s=0.97, \mathrm{n}=231, P<0.0001$ ), showing that the observed species richness in each cell depends on the sampling effort. Therefore, our current database shows that the observed distribution of endemic angiosperms is spatially biased. The first-order Jackknife estimator also demonstrates the bias of the survey effort. This estimator revealed that only five of 231 grid cells were well surveyed (Figure 1b). The observed species richness values in these well-surveyed grid cells ranged from 247 to 978 species, while the species richness estimated by the jackknife varied from 351 to 1,376 species. These grid cells are distributed in only four sites, in southern Bahia, west Rio de Janeiro, eastern Paraná and eastern Santa Catarina. Except the grid cell in eastern Santa Catarina, these correspond to the richest cells mentioned above. However, there are many regions that lack well-surveyed sites, even in grids with high values of endemic species richness, as in the central Espírito Santo and eastern São Paulo.

The relationship between species richness by latitude follows a multimodal distribution, with three peaks decreasing represented by latitudes $22^{\circ} \mathrm{S}$ ( 1,570 species), $14^{\circ} \mathrm{S}$ (607 species) and $8^{\circ} \mathrm{S}$ (159 species) (Figure 2). The D'Agostino-Pearson test not verified a normal distribution and is right-skewed $\left(\mathrm{K}^{2}\right.$ test $=20.79, P<0.0001$; skewness, $g_{1}=1.557$; kurtosis, $g_{2}=2.873$ ).

Considering the total number of endemic angiosperms studied, the Atlantic Forest Biodiversity Corridors host $85 \%$ of the endemism. The highest endemic angiosperm richness was found in Serra do Mar Corridor (2,006 species), followed by Atlantic Forest Central Corridor (1,521 species) and Northeastern Biodiversity Corridor (194 species). Almost $88 \%$ of endemic angiosperms examined occur in Priority Areas for Conservation in the Atlantic Forest. The 'extreme biological importance' category had the highest number of species (1,915 species), followed by the categories 'very-high biological importance' (944 species) and 'high biological importance' (812 species). About $58 \%$ of the species studied are in Brazilian Protected Areas. Only 10\% are restricted Strictly Protected category, $26 \%$ occur only in Sustainable Use category, and 22\% are present in both management categories. 


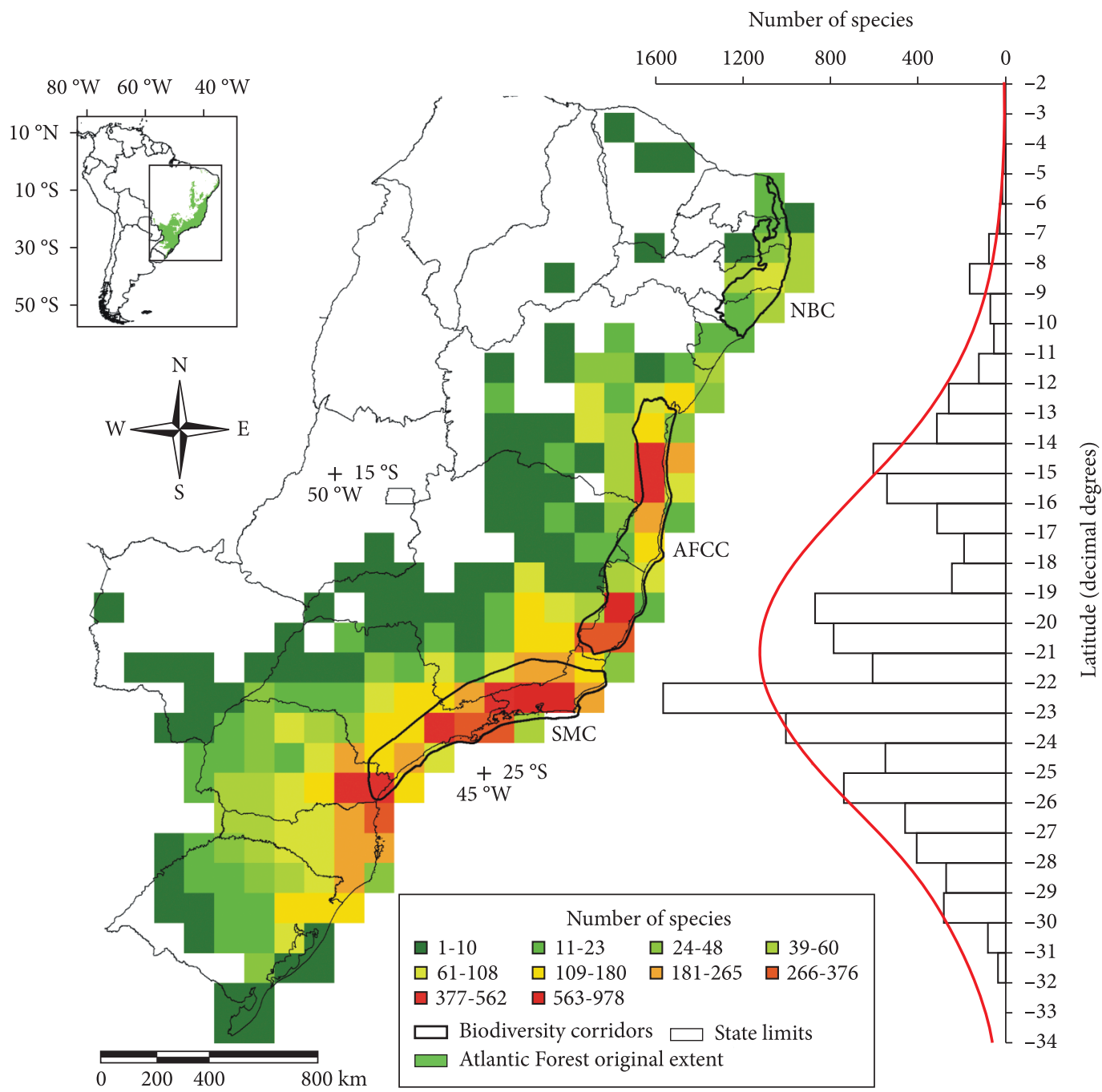

Figure 2. Species richness recorded in each $1^{\circ} \mathrm{x} 1^{\circ}$ grid cell and frequency distribution of latitudinal extents (in decimal degrees) for the distributional range of 3,345 endemic angiosperms of Atlantic Forest. The red line is the normal distribution curve. NBC: Northeastern Biodiversity Corridor; AFCC: Atlantic Forest Central Corridor; SMC: Serra do Mar Corridor.

\section{Discussion}

The areas with higher number of endemic species found in this study correspond, not surprisingly, to major herbaria or research centers (north to south), such as CEPLAC (Comissão Executiva do Plano da Lavoura Cacaueira) in southern Bahia, Museu de Biologia Professor Mello Leitão in central Espírito-Santo, Jardim Botânico do Rio de Janeiro and Museu Nacional de História Natural in central Rio de Janeiro, and Museu Botânico Municipal in southeastern Paraná. There is a potentially a strong sampling bias in these results, a "museum effect" (Ponder et al. 2001), implying that for historical reasons of efficiency, logistic, and convenience, collectors tend to over-sampled near these institutions. Furthermore, the survey directed towards localities previously recognized as having higher species richness values, such as mountain ranges or particularly wet areas, is unpromising for discovering the true species richness distribution in an area (Sastre \& Lobo 2009). This must be influencing the high species richness found in the mountainous areas of Rio de Janeiro, São Paulo and Paraná mentioned before. Some authors have shown that the unevenness in collecting activity affects the perception of centers of endemism (Ponder et al. 2001) and the selection of priority areas for conservation (Grand et al. 2007). Therefore, our data must be considered with extreme caution, and more representative inventories should be allocated to areas poorly sampled to correct for the geographical bias in the effort to record occurrences.

Even so, it is possible to see that the area of higher endemic angiosperm richness includes several mountain ranges with a clear altitudinal gradient. The attractiveness of different landscapes found in these mountainous areas contribute to the observed sampling bias. Furthermore, it 
is the largest inland region of the biome $\left(15^{\circ}\right.$ longitudinal amplitude), with a clear gradient of moisture and diversity of landscapes (Oliveira-Filho \& Fontes 2000). A second region of significant endemic angiosperm richness corresponds to a range of sites of high biodiversity recognized for several floristic inventories (Amorim et al. 2009). In this case, the preference of study sites based on the researcher's interest is notorious. The third and last area with high endemic numbers represents the latitudinal band where most brejos (evergreen to semideciduous forest islands located in the slopes of residual plateaus in the Caatinga region) occur, containing significant endemic angiosperms richness (Siqueira-Filho et al. 2006). The survey effort is targeted to these sites and also contributes to the geographic bias. The taxonomists repetitively select localities that are historically recognized as having greater values of biodiversity and the biases in the information stored in biodiversity databases are therefore the result of a directed research effort (Dennis \& Thomas 2000). This bias is clearly seen in our results.

All three modes also coincide with the presence of historical forest refugia in the Atlantic Forest (Carnaval et al. 2009). Furthermore, all grid cells of endemic angiosperms richness also reflect current opinion on centers of endemism in the Atlantic Forest in several different groups of organisms (Aguiar et al. 2003). These are also regions where the sampling effort has been concentrated since the early naturalists arrived in Brazil. It should be noted that our data do not confirm the occurrence of three centers of endemism, because the sampling bias strongly influences the three-modal distribution. The three areas of endemism for woody plants proposed by Prance (1987) coincidentally correspond to the latitudinal bands with the highest values of richness of endemic species in this study. Murray-Smith et al. (2008) found two areas of endemism, coincident with most of our grid cells richest in endemic species, but are related to sites of high collecting intensity. A very strong association between centers of endemism for plants and collecting effort was also found by Nelson et al. (1990) in Amazonia.

From south to north, the first gap in richness of angiosperms corresponds to region that has lost much of its original forest cover, with few remaining forest fragments (Coimbra-Filho \& Câmara 1996). The second gap occurs in a latitudinal band in which the Atlantic Forest is originally restricted to a small coastal strip, being dramatically destroyed by the Portuguese colonization in the 18th century, also with few remnants of vegetation (Coimbra-Filho \& Câmara 1996). We emphasize that there was no significant decrease of endemic species richness in region of Campos dos Goitacazes, northern Rio de Janeiro State, which has a pronounced seasonal climate near the coast (Oliveira-Filho \& Fontes 2000), and could represent a barrier to the distribution of endemic species dependent on a constant moist environment.

Although there is sample bias, as previously highlighted, the results presented here serve as a good guide for conservation of endemic angiosperms in the Atlantic Forest. Biodiversity Corridors are confirmed as important management units for conservation of endemic angiosperms in Atlantic Forest, since most species are covered by them. The Priority Areas for Conservation also include most of endemic angiosperms and are essential management units for conservation. On the other hand, less than a third of endemic angiosperms occur in Strictly Protected Areas. Many of them lack the basic apparatus necessary to effectively maintain biodiversity, such as financial resources, infrastructure, insufficient technical personnel and equipment to direct and guard the units, problems related to land tenure documentation, and management plans to guide the actions of managers (Fonseca et al. 2010). About a quarter occur in Protected Areas of Sustainable Use, which often do not provide effective protection. Therefore, although Biodiversity Corridors and Priority Areas for Conservation are important management units for conservation, few species are present in Strictly Protected Areas, the ones that in fact could enhance protection.

The distribution of endemic angiosperms in the Atlantic Forest shows that further studies need to be developed. An important issue relates to conducting floristic inventories in regions with knowledge gaps, aiming to correct the geographical bias in sampling effort. Since most of the endemic angiosperms used in this study are outside Strictly Protected Areas, strategies to protect these species in the Atlantic Forest should be drawn up, in particular for those that are threatened. In this sense, evaluate the risk of extinction for each endemic angiosperm species is important to formulate conservation strategies for this unique biological heritage of the Atlantic Forest.

\section{Acknowledgements}

We thank Critical Ecosystem Partnership Fund - CEPF for support the project Vascular Plant Endemism in the Atlantic Forest Biome, and Coordenação de Aperfeiçoamento de Pessoal de Nível Superior - CAPES and Conselho Nacional de Desenvolvimento Científico e Tecnológico for grants received. We are also grateful to the following researchers: André Amorim (Herbário Centro de Pesquisas do Cacau, CEPEC), Hélio B. Fernandes (Museu Biológico Mello Leitão, MBML), Carmen Zickel (Universidade Federal Rural de Pernambuco, PEUFR), Rita de Cássia A. Pereira (Empresa Pernambucana de Pesquisa Agropecuária, IPA ), Rafaela Forzza (Jardim Botânico do Rio de Janeiro, RB), Gert Hatschbach (Museu Botânico Municipal, MBM) e Inês Cordeiro (Instituto de Botânica, SP). We are indebted to Caetano T. Oliveira, Flavio D. Gontijo, Nara F. de Oliveira Mota and Rafaella C. Ribeiro for their help getting data in herbaria and taxonomic literature.

\section{References}

Aguiar AP et al., 2003. The Central and Serra do Mar Corridors in the Brazilian Atlantic Forest. In Galindo-Leal C \& Câmara IG (eds.), The Atlantic Forest of South America: biodiversity status, trends, and outlook. Washington: Center for Applied Biodiversity Science e Island Press. p. 118-132. 
Amorim AM et al., 2009. Angiospermas em remanescentes de floresta montana no sul da Bahia, Brasil. Biota Neotropica, 9:313-348. http://dx.doi.org/10.1590/ S1676-06032009000300028

Brose U, Martinez ND \& Williams RJ, 2003. Estimating species richness: sensitivity to sample coverage and insensitivity to spatial patterns. Ecology, 84:2364-2377. http://dx.doi. org/10.1890/02-0558

Carnaval AC et al., 2009. Stability predicts genetic diversity in the Brazilian Atlantic forest hotspot. Science, 323:785-789. PMid:19197066. http://dx.doi.org/10.1126/science.1166955

Coimbra-Filho AF \& Câmara IG, 1996. Os limites originais do bioma Mata Atlântica na Região Nordeste do Brasil. Rio de Janeiro: Fundação Brasileira para a Conservação da Natureza.

Colwell RK \& Coddington JA, 1994. Estimating terrestrial biodiversity through extrapolation. Philosophical Transactions of the Royal Society of London, Series B, Biological Sciences, 345:101-118. PMid:7972351. http://dx.doi.org/10.1098/ rstb.1994.0091

Conservation International do Brasil et al., 2000. Avaliação e ações prioritárias para a conservação da biodiversidade da Mata Atlântica e Campos Sulinos. Brasília: Secretaria de Biodiversidade e Florestas, Ministério do Meio Ambiente.

Dennis RLH \& Thomas CD, 2000. Bias in butterfly distribution maps: the influence of hot spots and recorder's home range. Journal of Insect Conservation, 4:73-77. http://dx.doi. org/10.1023/A:1009690919835

Environmental Systems Research Institute - ESRI, 2004. ArcGIS 9: Getting started with ArcGIS. Redlands: ESRI.

Fonseca M, Lamas I \& Kaseker T, 2010. O papel das unidades de conservação. Scientific American Brasil Especial, 39:18-23.

Forzza RC et al., 2010. Catálogo de plantas e fungos do Brasil. Rio de Janeiro: Instituto de Pesquisas Jardim Botânico do Rio de Janeiro. 2 vol.

Forzza RC et al., 2011. Lista de Espécies da Flora do Brasil 2011. Available from http://floradobrasil.jbrj.gov.br/2011. Accessed on October 2011.

Grand J et al., 2007. Biased data reduced efficiency and effectiveness of conservation reserve networks. Ecology Letters, 10:364-374. PMid:17498135. http://dx.doi. org/10.1111/j.1461-0248.2007.01025.x

Harrison S et al., 2006. Regional and local species richness in an insular environment: serpentine plants in California. Ecological Monographs, 76:41-56. http://dx.doi. org/10.1890/05-0910

Hortal J \& Lobo JM, 2005. An ED-based protocol for the optimal sampling of biodiversity. Biodiversity and Conservation, 14:2913-2947. http://dx.doi.org/10.1007/s10531-004-0224-z

Hortal J, Borges PAV \& Gaspar C, 2006. Evaluating the performance of species richness estimators: sensitivity to sample grain size. Journal of Animal Ecology, 75:274287. PMid:16903065. http://dx.doi. org/10.1111/j.1365-2656.2006.01048.x

Mittermeier RA et al., 2004. Hotspots revisited: earth's biologically richestand most endangered terrestrial ecoregions. Washington: Cemex.

Murray-Smith C et al., 2008. Plant diversity hotspots in the Atlantic coastal forests of Brazil. Conservation Biology, 23:151-163. PMid:18950472. http://dx.doi. org/10.1111/j.1523-1739.2008.01075.x

Nelson BW et al. 1990. Endemism centres, refugia, and botanical collection density in Brazilian Amazonia. Nature, 345:714-716. http://dx.doi.org/10.1038/345714a0

Oliveira-Filho AT \& Fontes MAL, 2000. Patterns of floristic differentiation among Atlantic Forests in southeastern Brazil and the influence of climate. Biotropica, 32:793-810.

Peterson AT \& Watson DM, 1998. Problems with areal definitions of endemism: the effects of spatial scaling. Diversity and Distributions, 4:189-194. http://dx.doi. org/10.1046/j.1472-4642.1998.00021.x

Ponder WF et al., 2001. Evaluation of museum collection data for use in biodiversity assessment. Conservation Biology, 15:648657. http://dx.doi.org/10.1046/j.1523-1739.2001.015003648.x

Prance GT, 1987. Biogeography of neotropical plants. In: Whitmore TC \& Prance GT (eds.). Biogeography and Quaternary History in Tropical America. Oxford: Clarendon Press. p. 46-65.

Sánchez-Fernández D et al., 2008. Bias in freshwater biodiversity sampling: the case of Iberian water beetles. Diversity and Distributions, 14:754-762. http://dx.doi. org/10.1111/j.1472-4642.2008.00474.x

Sanderson J et al., 2003. Biodiversity conservation corridors: planning, implementing, and monitoring sustainable landscapes. Washington: Conservation International.

Sastre P \& Lobo JM, 2009. Taxonomist survey biases and the unveiling of biodiversity patterns. Biological Conservation, 142:462-467. http://dx.doi.org/10.1016/j.biocon.2008.11.002

Silva M, 2005. The Brazilian Protected Areas Program. Conservation Biology, 19:608-611. http://dx.doi. org/10.1111/j.1523-1739.2005.00707.x

Siqueira-Filho JA et al., 2006. Atlantic Forest Fragments and Bromeliads in Pernambuco and Alagoas: Distribution, Composition, Richness and Conservation. In: Siqueira-Filho JA \& Leme EMC (eds.). Fragmentos de Mata Atlântica do Nordeste, Biodiversidade, Conservação e suas Bromélias. Rio de Janeiro: Andrea Jakobsson Estúdio. p. 100-131.

Soberón J et al., 2007. Assessing completeness of biodiversity databases at different spatial scales. Ecography, 30:152-160.

Stehmann JR et al., 2009. Plantas da Floresta Atlântica. Rio de Janeiro: Instituto de Pesquisas Jardim Botânico do Rio de janeiro. 